\title{
PENGENDALIAN INTERN TERHADAP SISTEM PENGAWASAN PRODUKSI DAN SISTEM BIAYA (STUDI KASUS PT. XYZ)
}

\author{
Julisar \\ Jurusan Sistem Informasi, Fakultas Ilmu Komputer, Bina Nusantara University \\ Jln. K.H. Syahdan No 9, Palmerah, Jakarta Barat 11480 \\ julisar@binus.ac.id
}

\begin{abstract}
Business use internal control to guide their operations, safeguard assets and prevent abuses their system. Management is responsible for designing and applying five elements of internal control. The results from the evaluation of Internal Control in Production Control System and Cost System are the company has a good enough internal control in both their systems, such as, implement the segregation of duties, effective and efficiency in their manual operation procedure, controlling their documents and assets. But one thing the company needs to be done is the using of pre-numbered form. Most of all their forms have not been a prenumbered form.
\end{abstract}

Keywords: internal control, production control system, cost system.

\begin{abstract}
ABSTRAK
Bisnis menggunakan pengaturan internal untuk memandu operasi, mengamankan aset, dan mencegah kerusakan sistem. Manajemen bertanggung jawab untuk mendesain dan mengaplikasikan lima elemen dari pengaturan internal. Hasil dari evaluasi pengaturan internal dalam sistem pengaturan produksi (production control system) dan sistem pembiayaan (cost system) adalah bahwa perusahaan memiliki pengaturan internal yang cukup bagus dalam sistem mereka, seperti implementasi segregasi tugas, efektif dan efisien dalam prosedur operasional manual, pengaturan dokumen dan aset. Tetapi satu hal yang perlu dilakukan perusahaan adalah menggunakan bentuk pre-numbered.
\end{abstract}

Kata kunci: pengaturan internal, sistem pengaturan produksi, sistem pembiayaan. 


\section{PENDAHULUAN}

Dewasa ini kebutuhan akan suatu Sistem Akuntansi yang baik dalam suatu perusahaan semakin terasa yaitu demi tercapainya kelancaran aktifitas perusahaan, efisiensi dalam kegiatan perusahaan serta untuk mencapai Pengendalian Intern yang memadai. Suatu pengendalian intern yang memadai memungkinkan dilaksanakan perencanaan, pengkoordinasian dan pengawasan terhadap seluruh aktifitas organisasi perusahaan yaitu, misalnya kurang adanya koordinasi dalam prosedur pengeluaran order produksi, yaitu koordinasi kepada bagian-bagian yang terkait dalam proses pengolahan produk seperti jangka waktu pengolahan barang produksi.

Manajemen berkepentingan untuk mengetahui keadaan perusahaan yang dipimpin-nya. Dalam perusahaan yang kecil, manajemen dapat langsung turun tangan mengawasi dan mengurusi pekerjaan yang ada dalam perusahaan. Tetapi apabila perusahaan sudah semakin besar dan meluas maka manajemen tidak dapat lagi mengawasi dan mengurusi pekerjaan yang ada dalam perusahaan, karena keterbatasan rentang pengendalian (span of control) dan waktu, oleh karena itu sebagian tugas dan wewenang dari manajemen akan didelegasikan kepada orang lain.

Pendelegasian tugas kepada orang lain dilakukan dengan harapan agar pelaksanaan dari kegiatan perusahaan bisa berjalan dengan lancar. Selain itu diperlukan suatu pengawasan untuk mengetahui apakah kebijaksanaan yang telah ditetapkan oleh manajemen sudah dijalankan dengan semestinya dan untuk mengetahui kemajuan yang telah dicapai. Untuk itu manajemen memerlukan suatu sistem informasi yang penting dalam suatu perusahaan yaitu yang disebut dengan Sistem Akuntansi.

Suatu sistem akuntansi yang baik tergantung kepada Pengendalian Intern yang dibangun di dalam-nya. Dalam menyusun sistem akuntansi kita harus memperhatikan segi biaya yang dikeluarkan dan dengan manfaat yang akan diperoleh atau dengan kata lain biaya yang sudah dikeluarkan (setidaknya) seimbang dengan manfaat yang diperoleh. Dengan adanya suatu pengendalian internal yang baik, maka manajemen dapat melaksanakan fungsinya dengan baik yaitu dapat menekan terjadinya kesalahan dan penyelewengan.

Salah satu sifat dari pengendalian internal yang baik adalah menggunakan orang-orang yang jujur dan cakap sesuai dengan fungsi yang ditangani. Dalam hal ini memilih karyawan harus diperhatikan kecakapan dan keahlian yang menyangkut pendidikan, pengalaman dan juga kepribadian yang menyangkut kecerdasan, kejujuran, kesabaran dan keuletan. Perusahaan ini bergerak dalam bidang usaha percetakan dan perdagangan. Kegiatan usaha yang dilakukan yaitu menerima order cetak yang berupa kartu nama, kop surat, amplop, label kaset, dan lain-lain. Ruang lingkup batasan penelitian ini, yaitu inti pembahasan adalah pengendalian intern terhadap sistem pengawasan produksi dan sistem biaya yang ada di kantor pusat. Prosedur dalam sistem pengawasan produksi dan sistem biaya yang mencakup formulir-formulir yang digunakan dalam melaksanakan suatu prosedur, unit kegiatan organisasi yang terlibat dalam melaksanakan suatu prosedur dan diagram alur yang berlaku di perusahaan saat ini.

Penelitian ini bertujuan untuk mengetahui hubungan antara sistem akuntansi dengan pengendalian internal. Tujuan sistem akuntansi suatu perusahaan adalah untuk mengidentifikasi, merakit, mengklarifikasi, menganalisa, mencatat dan melaporkan transaksi-transaksi perusahaan dan menyelenggarakan pertanggung-jawaban atas aktiva perusahaan yang dalam hal ini adalah persediaan.

Agar lebih jelas dan terarah dalam membahas persoalannya, maka melalui pertanyaanpertanyaan berikut ini, akan dicoba untuk mencari jawaban-nya; apakah struktur organisasi perusahaan telah tersusun sedemikian rupa sehingga di satu pihak tenaga para karyawan dapat dimanfaatkan 
sebaik mungkin tetapi di lain pihak sekaligus terdapat pemisahan wewenang untuk maksud-maksud pengendalian internal? Apakah masing-masing karyawan telah dibebani tanggung jawab sesuai dengan kecakapannya, pengalamannya atau dengan kata lain sesuai dengan pepatah the right man in the right place? Bagaimana pertanggungjawaban hasil kerja masing-masing karyawan dalam pelaksanaan sehubungan dengan pengawasan dan penilaian atasan? Karena sesuai dengan prinsipprinsip manajemen, seorang atasan harus menilai hasil pekerjaan bawahannya dan jika perlu mengadakan tindakan koreksi demi kepentingan perusahaan; dan apakah terdapat pemisahan fungsi antara fungsi pelaksanaan, fungsi penyimpanan, fungsi pengurusan dan fungsi pengawasan? Hendaknya ada pembagiana tugas untuk masing-masing karyawan sehingga tidak ada yang mengerjakan suatu transaksi dari awal sampai akhir, misalnya tergabungnya fungsi pelaksanaan, fungsi penyimpanan, fungsi pencatatan dan fungsi pergudangan oleh satu orang. Pada setiap transaksi yang penting, harus diikutsertakan paling sedikit 2 orang dan kemudian hasil kerja mereka digunakan sebagai alat control; apakah secara periodik (berkala) sistem akuntansi diteliti kembali yaitu apakah sesuai dengan kondisi dan keadaan perusahaan pada saat tertentu?

Perlu sekali me-review sistem perusahaan yang telah berjalan, yaitu yang disebabkan oleh berkembangnya perusahaan misalnya untuk memperluas sistem dan prosedur yang berjalan. Agar dapat mengikuti perkembangan perusahaan tersebut maupun kemungkinan perusahaan untuk melakukan perluasan sehingga perlu diadakan perubahan-perubahan terhadap sistem dan prosedur yang dijalankan semula.

\section{METODE}

Metode Penelitian yang digunakan yaitu studi kepustakaan dan studi lapangan. Studi Kepustakaan, dilakukan untuk mencari dan mengumpulkan data informasi ilmiah sebagai dasar/bahan untuk membuat penelitian. Studi ini dilakukan dengan cara membaca buku-buku dan literatur serta tulisan-tulisan lain yang erat hubungannya dengan topik penelitian ini. Studi lapangan, dilakukan dengan melakukan peninjauan langsung ke perusahaan yang bersangkutan dan diskusi dengan pimpinan perusahaan. Pengumpulan data dari perusahaan dilakukan dengan cara wawancara. Wawancara yang peneliti lakukan yaitu dengan cara wawancara bebas terpimpin yaitu peneliti bebas memberikan pertanyaan-pertanyaan kepada responden (pimpinan perusahaan) tetapi tetap berpedoman terhadap hal-hal yang peneliti ingin ketahui. Pertanyaan-pertanyaan ini sudah peneliti buat daftarnya sehingga lebih mudah untuk memberikan pertanyaan.

Penelitian ini dilakukan dengan mengolah data langsung dari sumbernya yaitu dalam hal ini perusahaan sebagai sumber primer, sedangkan bahan sekunder dari bahan-bahan kepustakaan yang ada. Dari kedua sumber tersebut yang penulis pergunakan, maka dalam era globalisasi saat ini, hubungan antara sistem akuntansi dengan Pengendalian Intern adalah sangat erat, baik untuk perencanaan maupun untuk pengendalian perusahaan. Sistem pengawasan produksi terdiri dari jaringan prosedur untuk mengawasi order produksi yang dikeluarkan agar terjadi koordinasi antara kegiatan penjualan, penyediaan bahan baku, fasilitas pabrik dan penyediaan tenaga kerja guna memenuhi order tersebut.

Prosedur pengawasan produksi adalah prosedur yang dimulai dari dikeluarkannya order produksi, mengikuti pelaksanaannya. Dalam membuat order produksi, perlu dipertimbangkan tersedianya bahan, kapasitas pabrik dan kemampuan karyawan. Order produksi biasanya dibuat beberapa lembar dan dikirimkan kepada tiap-tiap bagian yang mengerjakan order tersebut. Prosedur pangawasan produksi ini erat hubungannya dengan prosedur pesanan penjualan, prosedur pengiriman dan prosedur pembelian. $\quad$ Formulir order produksi dapat dibuat oleh pabrik (bagian produksi) 
berdasarkan pesanan dari langganan yang diterima oleh Bagian Penjualan atau dibuat berdasarkan rencana produksi yang disusun oleh Bagian Produksi dan Bagian Penjualan.

Ada dua jenis prosedur pengawasan produksi, yaitu: (1) prosedur pengawasan order produksi khusus yaitu suatu order produksi dikeluarkan untuk meminta pabrik agar memproduksi sejumlah produk tertentu. Prosedur ini digunakan apabila produk dapat diikuti dan dipisah dari proses yang lain. Yang termasuk model atau jenis prosedur pengawasan produksi khusus adalah produksi barang-barang untuk memenuhi pesanan dari pembeli yang spesifikasinya ditentukan oleh pembeli, produksi barang mode untuk memenuhi pesanan dari pembeli, pengirimannya dilakukan pada waktu yang akan datang, produksi suku cadang untuk persediaan atau dijual (yang diproduksi berdasarkan pesanan dari konsumen); dan (2) prosedur pengawasan produksi berulang yaitu prosedur yang sebuah order produksi dikeluarkan untuk meminta pabrik agar memproduksi produk tertentu selama 1 periode yang akan datang. Produksi ini digunakan apabila produk tidak dapat diikuti atau dipisah-pisahkan dari proses yang berurutan.

Unit organisasi yang terkait dengan Sistem Pengawasan Produksi, yaitu: (1) bagian penjualan, berfungsi untuk meneruskan penerimaan pesanan dari langganan yaitu apabila produksinya didasarkan atas pesanan. Penerimaan pesanan ini kemudian diteruskan ke departemen produksi. Bagian penjualan ini berkewajiban untuk menjaga pesanan dari langganan, artinya apabilan perusahaan sudah menyediakan formulir order produksi, maka bagian penjualan dapat langsung menyerahkan pesanan produksi ini ke departemen produksi, tetapi apabila pesanan produksi tidak menyediakan informasi yang lengkap, maka bagian penjualan wajib menambahkan informasi yang lengkap mengenai spesifikasi pesanan dari langganan. Untuk perusahaan yang memproduksi barang secara massal, maka pesanan produksi biasanya ditentukan dalam rapat bulanan antara departemen pemasaran, departemen produksi dan departemen teknik. bagian penjualan melayani pesanan dari langganan berdasarkan persediaan barang jadi yang ada di gudang; (2) bagian perencanaan dan pengawasan produksi, berfungsi sebagai staff pembantu departemen produksi dalam merencanakan dan mengawasi kegiatan produksi (3) departemen produksi, berfungsi membuat perintah produksi untuk bagian-bagian yang ada di bawahnya yang akan terkait dalam pelaksanaan proses produksi guna memenuhi permintaan produksi dari bagian penjualan. Surat pesanan produksi ini dilampiri dengan surat kebutuhan bahan dan daftar kegiatan produksi (4) bagian produksi, bertanggung jawab atas pelaksanaan produksi sesuai dengan surat pesanan produksi yang diterima dari departemen produksi yang daftar kebutuhan bahan serta daftar kegiatan produksi yang melampiri surat pesanan produksi tersebut (5) bagian gudang, bertanggung jawab atas pelayanan permintaan bahan baku, bahan penolong dan barang yang lain yang berada di dalam gudang. Bagian gudang ini juga menerima produk jadi yang diserahkan oleh fungsi produksi.

Jaringan prosedur yang membentuk sistem pengawasan produksi, yaitu prosedur pesanan produksi; prosedur permintaan dan pengeluaran barang gudang; prosedur pengembalian barang gudang; prosedur pencatatan jam tenaga kerja langsung; dan prosedur produk selesai.

\section{Sistem Biaya}

Sistem Biaya terdiri dari jaringan prosedur untuk mengumpulkan, mengklarifikasikan data biaya produksi dan biaya non-produksi untuk menyajikan informasi biaya bagi kebutuhan manajemen. Jaringan prosedur yang membentuk sistem pengawasan produksi dan sistem biaya, yaitu prosedur order produksi; prosedur permintaan dan pengeluaran barang gudang; prosedur pengembalian barang gudang; prosedur pencatatan jam kerja dan biaya tenaga kerja langsung; prosedur produk selesai dan pencatatan pembebanan biaya overhead pabrik; prosedur pencatatan biaya overhead pabrik sesungguhnya, biaya administrasi dan umum, dan biaya pemasaran. Unit organisasi yang terkait dalam sistem biaya yaitu bagian penjualan; bagian produksi; bagian perencanaan dan pengawasan produksi; bagian gudang; bagian kartu persediaan dan kartu biaya yang berfungsi sebagai pencatat persediaan 
dan biaya, yang bertanggung jawab atas pencatatan mutasi setiap jenis persediaan dan biaya produksi langsung, biaya produksi tidak langsung serta biaya non produksi ke kartu biay serta bagian jurnal, buku besar dan laporan berfungsi sebagai pencatat jurnal dan buku besar yang bertanggung jawab atas pencatatan transaksi terjadinya biaya bahan baku, biaya tenaga kerja, biaya oeverhead pabrik, dan biaya non produksi ke dalam jurnal pemakaian bahan baku dan jurnal umum serta posting ringkasan jurnal tersebut ke rekening yang bersangkutan dalam buku besar.

\section{Pengertian Pengendalian Intern}

Tujuan penyusunan suatu sistem akuntansi tidak lepas dari peningkatan pengendalian intern. Suatu sistem pengendalian intern yang baik menurut Mulyadi (2001) harus meliputi: organisasi, sistem otorisasi dan prosedur serta praktik yang sehat.

\section{Organisasi}

Fungsi pencatat biaya harus terpisah dari fungsi produksi; fungsi pencatat biaya harus terpisah dari fungsi yang menganggarkan biaya; fungsi gudang harus terpisah dari fungsi produksi; fungsi gudang harus terpisah dari fungsi akuntansi.

\section{Sistem Otorisasi dan Prosedur Pencatatan}

Surat order produksi diotorisasi oleh kepala fungsi produksi; bukti permintaan dan pengeluaran barang gudang diotorisasi oleh kepala fungsi produksi yang bersangkutan; bukti kas keluar diotorisasi oleh kepala fungsi akuntansi keuangan; daftar kebutuhan bahan dibuat oleh fungsi perencanaan dan pengawasan produksi dan diotorisasi oleh kepala fungsi produksi; daftar kegiatan produksi dibuat oleh fungsi perencanaan dan pengawasan produksi dan diotorisasi oleh kepala fungsi produksi; kartu jam kerja diotorisasi oleh kepala fungsi produksi yang bersangkutan.

\section{Praktik yang Sehat}

Surat order produksi, bukti permintaan dan pengeluaran barang gudang, bukti kas keluar, bukti memorial, bernomor urut tercetak dan penggunaannya dipertanggungjawabkan; secara periodik dilakukan rekonsiliasi kartu biaya dengan rekening kontrol biaya dalam buku besar; secara periodik dilakukan penghitungan persediaan yang ada di gudang untuk dicocokan dengan kartu persediaan.

\section{Hubungan Pengendalian Intern dengan Sistem Akuntansi}

Prosedur pengendalian adalah kebijakan dan prosedur yang ditetapkan oleh manajer untuk mencapai tujuannya, selain dari unsur-unsur lingkungan pengendalian dan segi-segi sistem akuntansi. Terdapat banyak kebijakan dan prosedur seperti itu dalam setiap perusahaan. Menurut Arens \& Loebbecke (1988), suatu pendekatan terpadu, kebijakan dan prosedur meliputi: (1) pembagian tugas yang jelas, (2) prosedur otorisasi yang jelas, (3) dokumen dan catatan yang memadai (4) pengendalian fisik atas aktiva dan catatan serta (5) pengendalian fisik atas aktiva dan catatan.

\section{HASIL DAN PEMBAHASAN}

Jaringan prosedur yang membentuk Sistem Pengawasan Produksi di perusahaan yaitu prosedur order produksi, prosedur permintaan dan pengeluaran barang gudang, prosedur pencatatan jam tenaga kerja langsung, prosedur produk selesai. 
Prosedur Order Produksi melibatkan bagian penjualan, bagian produksi dan pengembangan, dan bagian produksi. Prosedur di bagian penjualan yaitu memperoleh order dari pemesan, membuat surat order cetak sebanyak 3 (tiga) lembar berdasarkan keinginan dari pemesan dan sekaligus melengkapi. Lembar ke-1 untuk pemesan; lembar ke-2 untuk bagian produksi dan pengembangan, sebagai dasar untuk membuat daftar kebutuhan bahan dan daftar kegiatan; lembar ke-3 untuk arsip; dan mengirimkan surat order cetak dari pemesan yang sudah dilengkapi informasi ke bagian produksi dan pengembangan.

Prosedur di bagian produksi dan pengembangan yaitu menerima surat order cetak lembar ke-2 dari bagian penjualan, membuat surat order produksi (dalam hal ini perusahaan menamakan formulir ini order mounting/cetak), berdasarkan informasi yang ada di surat order, membuat daftar kebutuhan bahan dan daftar kegiatan yang akan dilakukan oleh bagian produksi untuk memenuhi permintaan dari pemesan. Daftar kebutuhan bahan ini sudah menjadi satu dengan order mounting/cetak, membuat order mounting/cetak sebanyak 3 (tiga) lembar. Lembar ke 1 untuk bagian produksi yang dalam hal ini untuk proses cetak, lembar ke 2 untuk bagian produksi yaitu bagian desain, apabila produksi memerlukan desain, kemudian diberikan ke bagian film, lembar ke 3 mempunyai 2 fungsi, yaitu : (1) untuk mengambil barang (2) sebagai dokumen kontrol untuk produk yang telah selesai dikerjakan, sehingga dokumen ini diarsip sementara sesuai tanggal. Prosedur di bagian produksi yaitu menerima formulir order mounting/cetak lembar ke 1 dan lembar ke 2 dari bagian produksi dan pengembangan. Formulir ini kemudian didistribusikan ke bagian film dan bagian cetak.

\section{Evaluasi untuk Prosedur Order Produksi}

Kelebihan untuk prosedur order produksi adalah masing-masing fungsi organisasi sudah melaksanakan tugasnya, yaitu dalam hal pembagian tugas yang jelas. Perusahaan sudah mempunyai formulir tersendiri untuk mencatat keinginan dari pembeli yaitu formulir order cetakan. Dalam hal ini keinginan pembeli sudah tercantum, sehingga kesalahan akibat kesalah informasi dapat dihindarkan. Juga dalam formulir ini sudah dijanjikan tanggal selesai produksi. Hal ini berguna supaya pihak perusahaan, khususnya, dapat lebih memperhatikan tanggal penyelesaian produksi; dalam pemakaian formulir order mounting/cetak, yang sudah mencakup daftar kebutuhan bahan, maka bagian produksi dan perencanaan tidak perlu lagi membuat daftar kebutuhan bahan di formulir yang lain. Dari segi biaya, perusahaan sudah menghemat untuk pemakaian formulir; pemakaian lembar ke 3 dari order mounting/cetak yang sebagai alat kontrol dapat memberikan jaminan bahwa order dari pembeli sudah dilaksanakan sesuai dengan keinginan; dokumen telah diarsip sementara, yaitu sebagai pengendalian fisik atas catatan.

Kelemahan untuk prosedur order produksi: untuk formulir order cetakan, tidak terdapat prenumbered; untuk formulir order mounting/cetak juga tidak terdapat pre-numbered. Saran untuk prosedur order produksi: untuk formulir order cetakan, sebaiknya dengan formulir yang sudah prenumbered (formulir yang sudah tercetak nomor urutnya). Dengan formulir yang pre-numbered, maka pihak perusahaan, khususnya bagian penjualan akan mudah untuk mencari order cetakan yaitu apabila terjadi klaim dari pemesan atau apabila terjadi hal-hal yang lain; Untuk formulir order mounting/cetak, sebaiknya juga dengan formulir yang pre-numbered. Dengan memakai formulir yang pre-numbered, maka bagian produksi dan pengembangan mudah untuk memeriksa ulang terhadap bahan yang dikeluarkan apabila terjadi ketidaksesuaian permintaan bahan.

\section{Prosedur Permintaan dan Pengeluaran Barang-barang Gudang}

Uraian kegiatan tiap unit organisasi yang terkait dalam prosedur permintaan dan pengeluaran barang gudang adalah sebagai berikut:

\section{Bagian Produksi dan Pengembangan}


Setelah mengetahui jumlah kebutuhan bahan, maka Bagian Produksi dan Pengembangan membuat bon pengambilan kertas/barang sebanyak 4 (empat) lembar. Pendistribusian Formulir ini adalah sebagai berikut: lembar ke 1 untuk bagian gudang yaitu untuk mengambil barang yang dibutuhkan; Lembar ke 2 untuk bagian produksi yang dalam hal ini untuk proses cetak; lembar ke 3 mengarsip berdasarkan nomor urut; lembar ke 4 untuk bagian akuntansi yaitu untuk mencatat jumlah pemakaian kertas/barang di kartu persediaan. Setelah itu membuat perhitungan pendahuluan harga pesanan tertentu dan mengirimkannya ke bagian akuntansi untuk prosedur produk selesai dan pembebanan biaya overhead.

\section{Bagian Gudang}

Menerima lembar ke 1 bon pengambilan kertas / barang dari bagian produksi dan pengembangan, menyerahkan barang kepada bagian produksi, mencatat bon pengambilan kertas lembar ke 1 ke dalam kartu gudang, setiap ada pengambilan barang dari gudang (kertas, tinta, barangbarang) lain, maka bagian gudang membuat bukti pengambilan kertas/barang untuk periode tertentu, mengarsipkan bon pengambilan kertas/barang berdasarkan nomor urut.

\section{Bagian Produksi}

Menerima formulir bon pengambilan kertas/barang lembar ke 2 dari bagian produksi dan pengembangan; menerima barang dari gudang; dan memeriksa barang apakah sudah sesuai dengan permintaan.

\section{Bagian Akuntansi}

Menerima bon pengambilan barang lembar ke-4 dari bagian produksi dan pengembangan; mencatat pemakaian bahan baku sesuai dengan bon pengambilan barang pada kartu persediaan; membukukan transaksi menurut bon pengambilan barang ke dalam jurnal, buku besar, dan untuk membuat laporan; mengarsipkan bon pengambilan barang ke-4 berdasarkan nomor urut.

\section{Evaluasi}

Kelebihan prosedur permintaan dan pengeluaran barang gudang, masing-masing fungsi organisasi sudah melaksanakan tugasnya pada bagian gudang, apabila ada pengambilan barang, akan membuat bukti pengambilan barang. Dalam hal ini, pimpinan perusahaan dapat mengetahui jumlah pemakaian barang untuk setiap periode tertentu. Sehingga pimpinan perusahaan juga dapat melihat kekerapan jumlah barang yang dipakai, sehingga dapat meramalkan waktu untuk memesan barang; Untuk pengendalian intern, pada waktu barang diserahkan, bagian produksi sudah memeriksa kuantitas dan kualitas barang yang diperiksa, sehungga barang yang diminta adalah sesuai dengan permintaan; formulir sudah dirancang sehingga setiap bagian yang terlibat sudah mengetahui ukuran kertas yang dibutuhkan.

Kelemahan prosedur permintaan dan pengeluaran barang gudang: kolom nomor urut untuk formulir ini tidak tercetak (pre-numbered); tidak pencatatan pemakaian bahan ke dalam job order cost sheet; perhitungan pemakaian bahan hanya berdasarkan kalkulasi pendahuluan harga pesanan, yang pada akhirnya perhitungan ini dikirimkan ke bagian akuntansi sebagai perhitungan biaya pemakaian bahan. Saran untuk prosedur permintaan dan pengeluaran barang gudang adalah sebaiknya formulir yang digunakan adalah formulir yang pre-numbered, supaya keakuratan urutan nomor formulir dapat dipertanggung-jawabkan; perusahaan menggunakan job order cost sheet (kartu harga pokok produk pesanan) yaitu untuk mengetahui biaya bahan yang dikeluarkan untuk melakukan pekerjaan atas suatu produk pesanan tertentu. 
Untuk pemakaian tinta, barang jenis lain, peneliti tidak membahas perosedurnya lebih lanjut karena jenis tinta yang dipakai untuk setiap order produksi adalah hampir sama, kemudian untuk barang jenis lain, tidak semua produksi menggunakan lem, benang dan sebagainya. Tetapi pada prinsipnya, setiap pengambilan barang dari gudang mempunyai prosedur yang sama dengan prosedur pengambilan kertas dari guang. Untuk prosedur pengembalian barang gudang, prosedur pencatatan jam kerja langsung, prosedur produk selesai, akan diuraikan bersama dengan jaringan prosedur sistem biaya.

\section{Prosedur Sistem Biaya}

Jaringan Prosedur yang membentuk sistem pengawasan produksi dan sistem biaya, yaitu: prosedur order produksi, prosedur permintaan dan pengeluaran barang gudang, prosedur pengembalian barang gudang, prosedur pencatatan jam kerja dan biaya tenaga kerja langsung, prosedur produk selesai dan pencatatan pembebanan biaya overhead pabrik.

Pada sistem pengawasan produksi, peneliti sudah menguraikan tentang prosedur order produksi, prosedur permintaan dan pengeluaran barang gudang, pada bagian ini peneliti akan menguraikan jaringan prosedur yang ada di sistem biaya: prosedur order produksi, sudah diuraikan di sistem pengawasan produksi; prosedur permintaan dan pengeluaran barang, sudah diuraikan di sistem pengawasan produksi; prosedur pengembalian barang gudang; prosedur pencatatan jam kerja dan biaya tenaga kerja langsung; prosedur produk selesai dan pencatatan pembebanan biaya overhead pabrik. Uraian kegiatan tiap unit organisasi yang terkait dalam prosedur pengembalian barang gudang adalah sebagai berikut:

\section{Prosedur Pengembalian Barang Gudang}

\section{Bagian Produksi}

Membuat bukti pengembalian kertas/barang gudang (dalam perusahaan ini bukti pengembalian barang gudang dinamakan bon pengembalian kertas ke gudang) sebanyak 3 lembar; menyerahkan lembar ke 1 dan ke 2 bon pengembalian kertas ke gudang tersebut ke bagian gudang bersama dengan barang; mengarsipkan bon pengembalian kertas ke gudang lembar ke 3 menurut nomor urutnya.

\section{Bagian Gudang}

Menerima bon pengembalian barang ke gudang lembar ke 1 dan ke 2 dari bagian produksi bersama dengan barang, menandatangani lembar ke 1 bon pengembalian barang ke gudang sebagai tanda terima barang dan mengirim ke bagian akuntansi, mencatat jumlah barang yang tercantum dalam lembar ke 2 bon pengembalian barang ke gudang dalam kartu gudang, mengirimkan lembar ke 1 bon pengembalian barangke gudang ke bagian akuntansi untuk dicatat di kartu persediaan, dan mengarsipkan lembar ke 2 bon pengembalian barang ke gudang menurut nomor urut.

\section{Bagian Akuntansi}

Menerima lembar ke 1 bon pengembalian barang ke gudang dari bagian gudang, mencatat bon pengembalian barang ke gudang sesuai dengan bon pengambilan kertas ke dalam kartu persediaan, membukukan transaksi pengembalian barang ke gudang ke dalam jurnal, buku besar dan untuk membuat laporan, dan mengarsipkan bon pengembalian barang ke gudang lembar ke 1 menurut nomor urut. 


\section{Evaluasi}

Kelebihan prosedur pengembalian barang gudang masing-masing fungsi organisasi sudah melaksanakan tugasnya, kecuali bagian produksi dan pengembangan, yaitu tidak mengetahui adanya pengembalian barang gudang, padahal bagian produksi dan pengembangan yang membuat bon permintaan dan pengeluaran barang gudang. Prosedur ini sudah berfungsi sebagai suatu prosedur yang terorganisir sebab dalam hal pengembalian barang gudang, bagian gudang harus menandatangani bon pengembalian barang ke gudang sebagai tanda terima barang. Bagian gudang juga mencatat jumlah barang yang tercantum dalam bon pengembalian barang ke gudang dalam kartu gudang; untuk pengendalian intern, bagian gudang sudah melaksanakan fungsinya yaitu menandatangani bukti pengembalian barang gudang, hal ini sebagai alat kontrol yaitu bukti bahwa barang sudah dikembalikan.

Kelemahan prosedur pengembalian barang gudang adalah formulir yang digunakan tidak prenumbered, alasan pengembalian barang tidak dicantumkan, tidak ada pencatatan pengembalian barang ke dalam job order cost sheet (kartu harga pokok pesanan), dalam hal ini tidak dapat diketahui biaya bahan yang sesungguhnya dikeluarkan atas pesanan tertentu; bagian produksi dan pengembangan tidak mengetahui adanya pengembalian barang gudang.

Saran untuk prosedur pengembalian barang gudang yaitu (1) formulir yang digunakan adalah formulir yang pre-numbered, supaya apabila ada kesalahan mudah ditelusuri dan diharapkan tidak terjadi pemalsuan nomor formulir; (2) alasan pengembalian barang sebaiknya dicantumkan, supaya pengembalian barang tidak dilakukan sembarangan, tetapi adalah benar-benar karena barang tersebut tidak dapat digunakan atau karena ada alasan yang dapat diterima; (3) sebaiknya perusahaan menggunakan job order cost sheet yaitu untuk mengetahui biaya pemakaian bahan yang terjadi akibat adanya kegiatan produksi atas suatu pesanan, yang untuk prosedur pengembalian barang gudang ini yaitu untuk mengkalkulasi bahan yang tidak jadi dipakai. Selain itu biaya yang sesungguhnya terjadi dapat diketahui; (4) sebaiknya bagian produksi dan pengembangan mengetahui adanya pengembalian barang gudang. Dalam hal ini adalah suatu prosedur otorisasi dalam hal mengetahui adanya pengembalian barang gudang dan pengecekan pelaksanaan pekerjaan yang terpisah.

\section{Prosedur Pencatatan Jam Kerja dan Biaya Tenaga Kerja Langsung}

Uraian kegiatan unit organisasi yang terkait dalam prosedur pencatatan jam kerja dan biaya tenaga kerja langsung adalah (1) karyawan, mencatat jam kehadiran dan hari kehadiran di kartu hadir; (2) bagian akuntansi, berdasarkan kartu hadir, maka setiap hari sabtu, menghitung jumlah jam hadir dan hari hadir, membuat rekap daftar upah/gaji; (3) membuat bukti kas keluar sebanyak 2 lembar yang harus diotorisasi oleh kepala bagian keuangan dan akuntansi terlebih dahulu; (4) membukukan transaksi ke dalam jurnal umum, buku besar, dan untuk membuat laporan (5) mengarsipkan bukti kas keluar lembar ke 2 berdasarkan nomor urut.

\section{Bagian Kasir}

Menerima bukti kas keluar dan rekap daftar upah, membayar upah/gaji ke masing-masing karyawan, mengembalikan rekap daftar upah ke bagian akuntansi, mengarsip bukti kas keluar sesuai dengan nomor urut.

\section{Evaluasi}

Kelebihan prosedur pencatatan jam kerja dan biaya tenaga kerja langsung adalah perusahaan sudah menggunakan mesin pencatat waktu untuk mencatat jam hadir, hari hadir karyawan. Dengan menggunakan mesin pencatat waktu, maka keakuratan jam kehadiran dapat dipertanggung-jawabkan (dengan catatan waktu adalah sesuai dengan yang berlaku); untuk pengendalian intern, bagian 
akuntansi sudah melaksanakan fungsinya, yaitu meminta otorisasi atas pengeluaran kas kepada kepala bagian keuangan dan akuntansi. Otorisasi ini sebagai pengamanan atas harta perusahaan yang paling likuid yaitu kas.

Kelemahan prosedur pencatatan jam kerja dan biaya tenaga kerja langsung adalah formulir bukti kas keluar tidak pre-numbered tetapi nomor urut hanya ditulis dengan tangan; tidak ada pencatatan biaya upah yang sesungguhnya terjadi ke dalam kartu harga pokok produk pesanan. Saran untuk prosedur pencatatan jam kerja dan pembebanan biaya tenaga kerja langsung; sebaiknya perusahaan menggunakan formulir bukti kas keluar yang pre-numbered, supaya apabila ada bukti kas keluar yang terlewat mudah ditelusuri dan tidak dipalsukan; sebaiknya perusahaan menggunakan job order cost sheet (kartu harga pokok pesanan) yaitu untuk mengetahui biaya upah yang sesungguhnya terjadi.

\section{Prosedur Produk Selesai dan Pencatatan Pembebanan Biaya Overhead Pabrik}

Uraian kegiatan unit organisasi yang terkait dalam prosedur produk selesai dan pencatatan pembebanan biaya overhead pabrik adalah sebagai berikut:

\section{Bagian Produksi dan Pengembangan}

Setelah pesanan selesai dikerjakan, maka bagian produksi dan pengembangan, berdasarkan formulir order mounting/cetak lembar ke 3 mencocokan jumlah pesanan dan hasil produksi yang selesai dikerjakan dengan yang tercantum di order mounting/cetak; membuat laporan order cetak, mengarsip sementara sampai periode tertentu; membuat surat jalan sebanyak 3 lembar, yaitu lembar ke 1 bagian order penjualan, lembar ke 2 bagian akuntansi, dan lembar ke 3 arsip.

\section{Bagian Akuntansi}

Menerima surat jalan lembar ke-2 yaitu sebagai dasar untuk membuat faktur dan faktur pajak; menerima kalkulasi pendahuluan harga pesanan dari bagian produksi dan pengembangan; berdasarkan harga pesanan yang sudah ditentukan oleh bagian produksi, maka bagian akuntansi membukukan transaksi pesanan ke dalam jurnal umum, buku besar dan untuk membuat laporan.

\section{Evaluasi}

Kelebihan prosedur produk selesai dan pencatatan pembebanan biaya overhead pabrik masing-masing fungsi organisasi sudah melaksanakan tugasnya, yaitu pembagian tugas sudah jelas dan untuk pengendalian intern, bagian produksi dan pengembangan sudah melaksanakan fungsinya, yaitu memeriksa hasil produksi yang dipesan oleh pembeli. Dalam hal ini sudah melakukan pengecekan pelaksanaan kerja yang terpisah. Kelemahan prosedur produk selesai dan pembebanan biaya overhead pabrik : bagian akuntansi tidak membuat bukti memorial yaitu yang berfungsi untuk mencatat pembebanan biaya overhead yang terjadi. Karena pembukuan transaksi hanya dilakukan berdasarkan kalkulasi pendahuluan, maka akan sulit untuk mengetahui biaya yang sesungguhnya terjadi. Kalkulasi pendahuluan tersebut hanya bersifat sementara dan merupakan perkiraan biaya-biaya yang akan terjadi, tetapi belum tentu terjadi.

Saran untuk prosedur produk selesai dan pencatatan biaya overhead pabrik : sebaiknya menggunakan bukti memorial yaitu untuk mengetahui terutama pembebanan biaya overhead dan sebaiknya perusahaan menggunakan job order cost (kartu harga pokok produk pesanan) yaitu untuk mengumpulkan biaya-biaya yang sebenarnya terjadi, seperti biaya pemakaian bahan, biaya upah buruh, biaya overhead pabrik. Selain mengetahui biaya yang sesungguhnya terjadi untuk pesanan tertentu, selisih perkiraan biaya juga dapat diketahui. 


\section{PENUTUP}

Berdasarkan pembahasan di atas maka dapat disimpulkan bahwa perusahaan telah memisahkan masing-masing fungsi, sehingga tidak ada transaksi yang dilakukan dari awal sampai akhir oleh satu orang dan masing-masing karyawan sudah mengejakan pekerjaan-nya masing-masing sesuai dengan keahlian-nya masin-masing, secara periodik perusahaan mengadakan evaluasi atas sistem akuntansi, di perusahaan sudah ada organisasi formulir, catatan dan laporan yang dikoordinasi untuk menyediakan informasi yang dibutuhkan. Jaringan prosedur yang ada di perusahaan sudah menunjukkan satu kesatuan yaitu untuk melaksanakan kegiatan yang ada diperusahaan, dan walaupun tidak di semua bagian, ada karyawan yang merangkap pekerjaan di bagian tertentu yaitu untuk efisiensi, tetapi dari segi pengendalian intern, tidak ada pekerjaan yang dilakukan dari awal sampai akhir oleh satu orang.

Berikut saran guna meningkatkan pengendalian intern yaitu stock opname dilakukan minimal 4 kali dalam setahun terlebih untuk persediaan yang mempunyai perputaran yang cukup tinggi, formulir yang digunakan oleh perusahaan adalah formulir yang pre-numbered, menggunakan bukti memorial untuk mencatat pembebanan biaya overhead yang terjadi sehubungan dengan kegiatan produksi, menggunakan job order cost sheet (kartu harga pokok pesanan) guna memudahkan mengetahui biaya yang sesungguhnya terjadi untuk suatu produk pesanan dan memudahkan dalam menentukan tingkat harga yang cocok untuk pesanan tersebut apabila di lain waktu perusahaan memperoleh order pesanan yang hampir sama dengan pesanan yang sudah dibuat, menerapkan teknologi informasi untuk meningkatkan efisiensi dan efektifitas dan menggunakan digital printing untuk melaksanakan proses pencetakan

\section{DAFTAR PUSTAKA}

Arens, A. A., \& Loebbecke, J. K. (1988). Auditing: an Integrated Approach. New Jersey: Prentice Hall.

Mulyadi. (2001). Sistem Akuntansi (3rd ed.). Jakarta: Penerbit Salemba Empat. 